\title{
脳機能賦活に起因するマウス皮質組織血流のレーザー計測
}

\author{
草野 将史 ${ }^{1}$, 中山 遙 ${ }^{1}$, 正本 和人 ${ }^{2,3}$, 菅野 嚴 $^{3}$, 岡田 英史 ${ }^{1}$ \\ 1慶應義塾大学 理工学部（テ223-8522 神奈川県横浜市港北区日吉3-14-1) \\ 2電気情報通信大学 先端領域教育研究センター（ 1 182-8585 東京都調布市調布ヶ 丘1-5-1） \\ 3放射線医学総合研究所 分子イメージング研究センター（２63-8555 千葉市稲毛区穴川4-9-1）
}

\section{Laser Measurements of Blood Flow in Cortical Tissue of Mice Caused by Brain Activation}

\author{
Masashi KUSANO, ${ }^{1}$ Haruka NAKAYAMA, ${ }^{1}$ Kazuto MASAMOTO,${ }^{2,3}$ Iwao KANNO, ${ }^{3}$ and Eiji OKADA ${ }^{1}$ \\ ${ }^{1}$ Department of Electronics and Electrical Engineering, Keio University, \\ 3-14-1 Hiyoshi, Kohoku-ku, Yokohama, Kanagawa 223-8522 \\ ${ }^{2}$ Center for Frontier Science and Technology, The University of Electro-Communications, 1-5-1 Chofugaoka, Chofu, Tokyo 182-8585 \\ ${ }^{3}$ Molecular Imaging Center, National Institute of Radiological Sciences, 4-9-1 Anagawa, Inage, Chiba 263-8555
}

(Received January 29, 2012)

\begin{abstract}
We measured the cerebral blood flow (CBF) of mice by laser speckle flowgraphy (LSFG) and laser Doppler flowmetry(LDF). In LSFG, two parameters that indicate CBF, mean blur rate (MBR) and the reciprocal of correlation time $(\mathrm{CT})$, are calculated from speckle patterns. MBR is calculated from $2 \times 2$ pixels in successive three frames, but CT is calculated from $7 \times 7$ pixels in one frame. The CBF change is caused by the brain activation evoked by whisker stimulation, and the MBR and CT time courses measured by LSFG were compared with the time course by LDF to validate the temporal resolution of LSFG. Both MBR and CT time courses were highly correlated with the LDF results. The spatial resolution of the MBR map is higher than that of the CT map and MBR is less influenced by the noise.
\end{abstract}

Key Words: Cerebral blood flow, Laser speckle flowgraphy, Laser Doppler flowmetry

\section{1. はじめに}

脳で生じる神経活動は, 運動, 感覚, 言語などの機能 に対応して局在しており, 脳が活動している部位を測定 することは脳科学の研究を行う上で重要な課題となって いる，非侵襲的に脳活動を計測する技術には，脳波，脳 磁図といった脳神経活動と直接関係する信号を検出する ものと, 近赤外光イメージング法や機能的磁気共鳴イ メージング法などの脳神経活動に誘発された組織血液量 を捉えるものがある．脳神経活動による血流変化のメカ ニズムには解明されていない点も多く, 小動物を用いた 基礎研究が行われている ${ }^{1)}$. 光学的手法による非接触計 測技術は，神経血管カップリングに関する研究に大きく 貢献している，例えば，神経活動の計測は，膜電位感受 性色素を用いた光学計測法が開発されたことにより，電 極を刺入せずに脳活動の空間的な分布を計測することが 可能になった ${ }^{2}$ ，また，血流についてはレーザードップ ラー法による点測定が行われていたが3)，近年は，ス キャン型のレーザードップラー血流計 ${ }^{4}$ やレーザース ペックル法によって空間的な血流分布計測が行われるよ うになってきている ${ }^{5,6)}$ とくに，レーザースペックル 法は，レーザー光源と撮像素子で測定系が構成できるた め, 小動物の脳機能計測への応用が進んでいる.
レーザーを用いた組織血流計測に共通の問題点とし て, 流速評価值が組織散乱に依存する係数を含むため, 絶対流速值の測定ができず相対速度しか求められないと いうことがある。また，測定の妥当性に関しても対象組 織毎に検証を行うことが望ましい.このことから，レー ザースペックル法による脳血流の計測值を，従来からの 測定例が多いレーザードップラー法で測定した結果と比 較することで，その妥当性を検証する研究が行われてい る7)。レーザースペックル法には, 複数の流速評価值が 存在し, 測定対象の散乱特性などとの関係が異なってい る.そのため, 妥当性の検証についても流速評価值毎に 行う必要がある。

本研究では，レーザースペックル法による脳血流計測 において，流速評価值としてMean Blur Rate (MBR) 值 ${ }^{899}$ を用いることの妥当性を検証することを目的として，同 一個体のマウスの体性感覚野における神経活動による脳 血流変化を，レーザースペックル法とレーザードップ ラー法によって計測する。レーザースペックル法による 計測では, MBR值に加えて, 先行研究においてレー ザードップラー法との相関を比較することで妥当性が示 されている相関時間に基づく流速評価值 ${ }^{5-7)} に よ る$ 解析 も行い, MBR值と比較, 検討する. 


\section{2. レーザースペックル法による血流測定の原理}

2.1 レーザースペックル法

生体組織などの粗面にレーザーを照射すると, 結像面 に粗面からの散乱光がランダムな位相で干渉することに よる斑点模様(スペックルパターン)か観測される。組織 内の血流によって散乱体である血球が移動すると, 干涉 の条件が変化するためスペックルパターンも変化する.

スペックルパターンを画像として記録し，スペックルパ ターンの変化を解析することで, 組織内血流の空間分布 を計測することが可能となる，とくに近年は，露光時間 内にスペックルパターンが変化したことで生じるぶれに よるスペックルパターンのコントラスト低下を解析し， 血流を求める方法が主として用いられるようになってき ている.

\section{2 スペックル法の流速評価值}

血流速を $V$, スペックルパターンの輝度の平均值を $\langle I\rangle$, 輝度值の空間的な変化の標準偏差を $\sigma$ とすると, 血 流速とスペックルパターンのコントラストとの間には以 下の関倸が成立している

$$
V=A\left(\frac{\langle I\rangle}{\sigma}\right)^{2}
$$

ここで，Aは撮像時の露光時間，画素サイズ，スペック ルサイズ，対象組織の散乱特性などに依存する係数であ るが, 生体組織の上うな多重散乱系に扔いて係数Aを求 めることは困難である。そのため、レーザースペックル 法では，スペックルパターンから流速を求めるいくつか の手法が提案されている。本研究では, これまでに提案 されているスペックルパターンから求める流速評価值と して, 網膜血流や皮膚血流の計測に利用されている MBR值と, 小動物の脳血流計測に関する先行研究があ る相関時間を利用したCT值を用いることとした.

MBR值は, 対象領域の画素值の平均を分子, 偏差を 分母とする評価值であり ${ }^{8,9)}$, 本研究では, 連続する37 レームの画像の $2 \times 2$ 画素の領域を対象領域とし, 時空 間的に隣接している画素值の和の総和を分子, 差の絶対 值の総和を分母としてMBR值のマップを作成した.

CT值は, 個々のスペックルの輝度の時間変化に対す る相関時間 $\boldsymbol{c}_{\mathrm{c}}$ が流速と逆比例の関係にあることを用いた 評価值である。 スペックルのコントラストと相関時間の 関係は, 撮像素子の露光時間を $T$ とすると, 次式で与え られる

$$
\left(\frac{\sigma_{\mathrm{s}}}{\langle I\rangle}\right)^{2}=\frac{\tau_{\mathrm{c}}}{2 T}\left\{1-\exp \left(-2 T / \tau_{\mathrm{c}}\right)\right\}
$$

本研究では, 式(2)の関係を示すルックアップテーブル を作成し, 1 フレームの $7 \times 7$ 画素の領域を対象領域とし て求めた画素值の平均值 $\langle I\rangle$ と標準偏差啷から, ルック アップテーブルを用いて相関時間 $\tau_{\mathrm{c}}$ 求め, その逆数を CT值とした，血流速とCT值の間にも，対象組織の散乱 に依存する係数が存在するため, 絶対的な血流速を得る
ことができない，つまり，スペックル法によって求めら れるのは, MBR值, CT值とも相対的な血流速であり, このことはレーザードップラー法で求めた血流速につい ても同様である。

\section{3. 実験方法}

3.1 計測対象およびシステム

本研究に抢けるマウスの脳血流計測は, 放射線医学総 合研究所の研究倫理審査委員会の承認のもとに実施され た. C57BL/6Jマウス $(n=4)$ の体性感覚野周辺の頭蓋骨 を麻酔下に扔いて除去し，ガラスのクラニアルウインド ウを装着することで, 脳の皮質組織を直接観測できるよ うにした。脳血流計測は，マウスが回復した後に覚醒下 で行った。 クラニアルウインドウ部分を定位固定装置に 取り付け, 実体影微鏡下で体性感覚野を中心とする皮質 組織を観測した，マウスは覚醒しているため運動を行う こともあるが，浮遊したボールの上にマウスを載せた状 態で測定を行うことで，固定された頭部に負荷がかから ないようになっている ${ }^{10)}$.

レーザースペックル法による計測では，皮質組織を波 長780 nmの半導体レーザーで照射し, 実体顕微鏡に取 り付けたCCDカメラ $(400 \times 400$ 画素, 30 フレーム/秒)に 結像させることで, 皮質組織からの散乱光によるスペッ クルパターンを連続的に取得した。レーザー光は斜め方 向から入射し，さらに偏光板を用いることで，クラニア ルウインドウのガラス表面からの鏡面反射が測定に影響 を及ぼさないようにした，スペックル画像から，流速評 価值であるMBR值抒よびCT值を算出した，MBRの算出 は, 連続する 3 フレームの画像の $2 \times 2$ 画素の領域を対象 に行った. CT値は, 1 フレームの画像の $7 \times 7$ 画素の領域 を対象に算出した。

レーザードップラー法による計測は，レーザードップ ラー血流計(FLO-C1，オメガウェーブ)によって行っ た、レーザードップラー血流計の使用波長は $780 \mathrm{~nm}$,

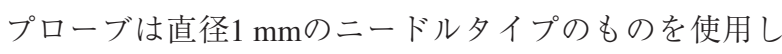
た。プローブ位置は，レーザースペックル法による測定 で最も大きな血流変化が観測された部位が測定領域の中 心になるように決定した，測定領域のクラニアルウイン ドウ上にプローブを設置してレーザーを照射・検出し， ガラス表面からの鏡面反射光が信号に与える影響が最小 になる角度で固定した。

\section{2 計測手順}

マウスの右側のヒゲにパルス状の空気刺激 $(69 \mathrm{kPa})$ を 与えることで体性感覚野を賦活させ，それに伴う血流速 の変化をレーザースペックル法によって計測した，測定 開始時は刺激を与えずに安静時の血流を5秒間測定し, その後2秒間あるいは20秒間の刺激を与えた，刺激パル スの周波数は, $2,5,10 \mathrm{~Hz}$ と, 各周波数について 15 セットの測定を行った、レーザースペックル法による計 測の後，同一個体のマウスを対象に同一の刺激条件に対 する脳血流変化をレーザードップラー法によって計測し 


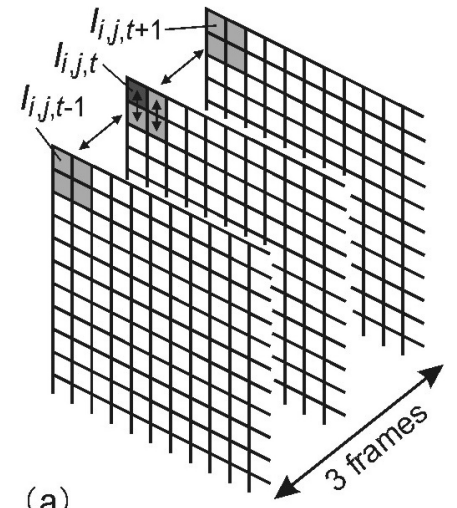

(a)

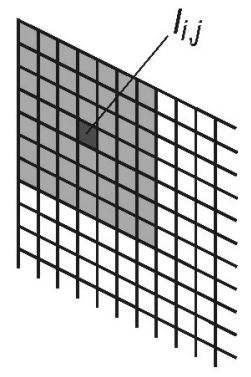

(b)

Fig. 1 Calculations of cerebral flow map by laser speckle flowgraphy. (a) mean blur rate (MBR). (b) speckle contrast (SC).

た. クラニアルウインドウ上に装着したプローブの位置 は，レーザースペックル法による計測で最も大きな血流 変化が観測された部位が測定領域の中央になるように設 定した。

\section{4. 結果と考察}

\section{1 スペックル法による脳血流マップ}

Fig. 2 (a)は, クラニアルウインドウを介してハロゲ ンランプ照明で観測したマウス皮質組織の画像を示して いる. 円形のクラニアルウインドウの開口部分に皮質組 織と表面の微小血管が観察されている. Fig. 2 (b) は, レーザーを照射したときの同一部位の画像である、組織 全体にスペックルパターンが生じ, 微小血管の位置など は不明膫になっている. 刺激開始前のベースライン計測 時のスペックルパターンから流速評価值であるMBR值 とCT值の分布を求めた脳血流マップをFig. 2 (c1)，(c2) にそれぞれ示す、いずれの脳血流マップにおいても， Fig. 2 (a)の血管領域に対応する部位で速い血流が観測 されていることが分かる.MBR值が $2 \times 2$ 画素の領域を 対象に算出しているのに対して, CT值は7 $\times 7$ 画素の領 域を対象としているため, CT值で求めた脳血流マップ の方が空間分解能は低くなる，そのため， CT值による 脳血流マップの血管領域の方が広がって観測されてい る. ラットのヒゲに周波数 $10 \mathrm{~Hz}$ の空気圧刺激を与え， 最も大きな血流変化が観測された時刻とベースライン計 測時の脳血流マップの差分を求め, ベースライン計測時 の值で正規化した結果をFig. 2(d1)，（d2)に示す. ヒゲ 刺激によって, 血流が増加した領域が白く表示されてお り, 画像右側の破線で囲われた領域を中心に血流の増加 がみられることから，この領域がヒゲに対応した体性感 覚野であると考えられる. Fig. 2 (a)のハロゲンランプ 照明で観測した画像では，毛細血管レベルの細い血管は コントラストが低く観測できていない，一方，スペック ル法では, 毛細血管レベルの血管内を移動する血球も干 渉条件の変化に寄与することになる。 しかし, 細い血管 内の血流は太い血管に比べて遅いため, Fig. 2 (c1),

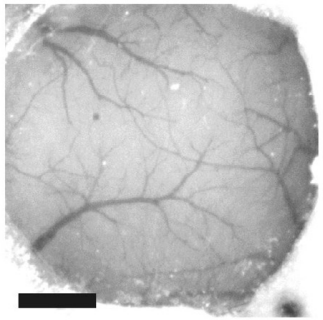

(a)

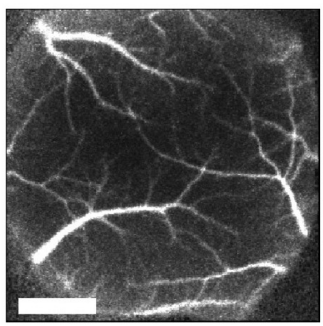

(c1)

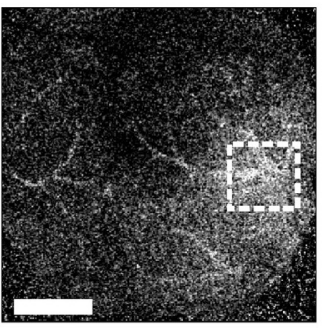

(d1)

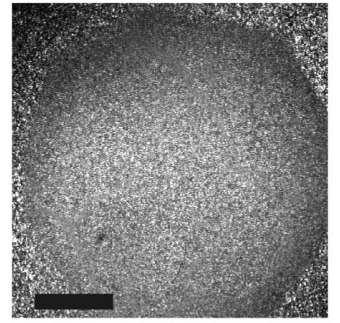

(b)

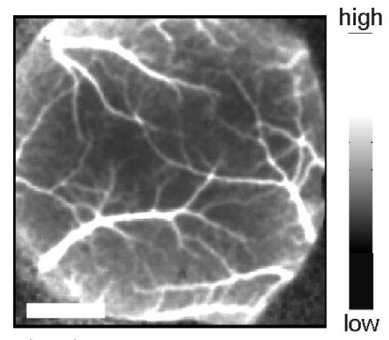

(c2)

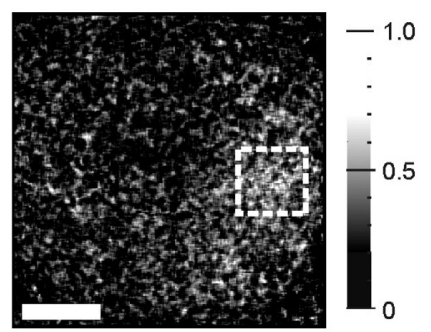

(d2)
Fig. 2 Cerebral blood flow measurements by laser speckle flowgraphy. (a) Cortical tissue of a mouse observed through a cranial window. (b) Raw speckle image. (c1) Distribution of MBR values calculated from raw speckle images. (c2) Distribution of speckle contrast values calculated from a raw speckle image. (d1) Distribution of the change in MBR values from the baseline. (d2) Distribution of the change in SC values from the baseline. The scale bar in each figure indicates $1 \mathrm{~mm}$.

(c2)の血流マップでは, 細い血管中の血流は明膫には観 測されていない. 一方, 血流変化を求めたFig. 2(d1), (d2)では, Fig. 2(a)に扔いて血管が観測されていない 領域においても血流の増加が認められ，ヒゲ刺激によっ て生じた毛細血管レベルの細い血管に扔ける血流変化が スペックル法によって捉えられていることが分かる.

\section{2 脳活動による脳血流変化}

マウスの脳活動に伴う脳血流変化をレーザースペック ル法で測定する場合に扔ける時間分解能の妥当性を検証 するため, レーザースペックル法とレーザードップラー 法で測定した脳血流の時間変化波形を比較した。レー ザースペックル法ではFig. 2 (d1)，（d2）に破線で示した ような, 最も大きな血流変化が観測された位置を中心と した $80 \times 80$ 画素の正方領域におけるMBR値またはCT値 の平均を，その時刻に扔ける血流変化值とした。レー ザードップラー血流計のプローブの影響によって，レー ザースペックル法とレーザードップラー法による脳血流 測定を同時に行うことができない，そこで，4頭のマウ 
スに対して行った脳血流計測の結果を加算平均した結果 を比較することとした．Fig. 3(a)，（b1），(b2)は，ヒゲ に周波数 $2 \sim 10 \mathrm{~Hz}$ の空気圧刺激を 2 秒間与えたときの脳 血流の時間変化を, レーザードップラー法，MBR值と CT值を用いたレーザースペックル法で計測した結果を

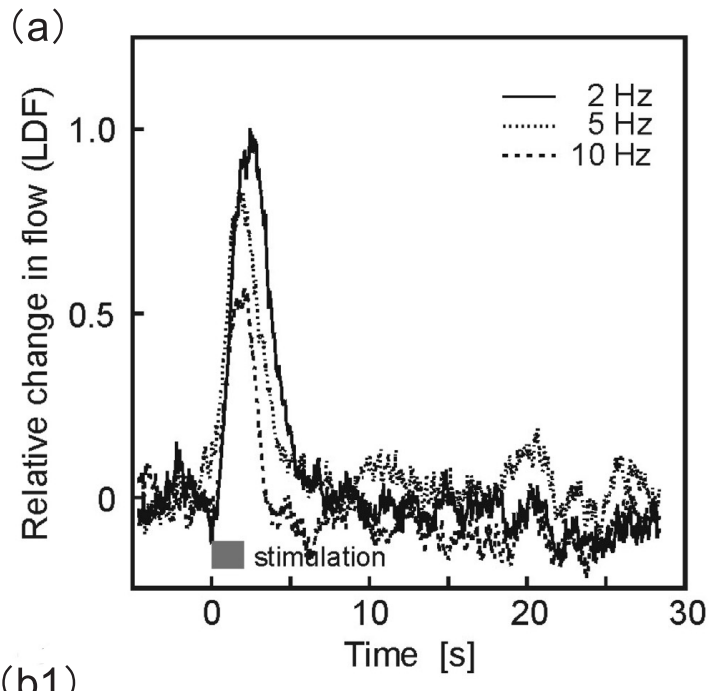

(b1)
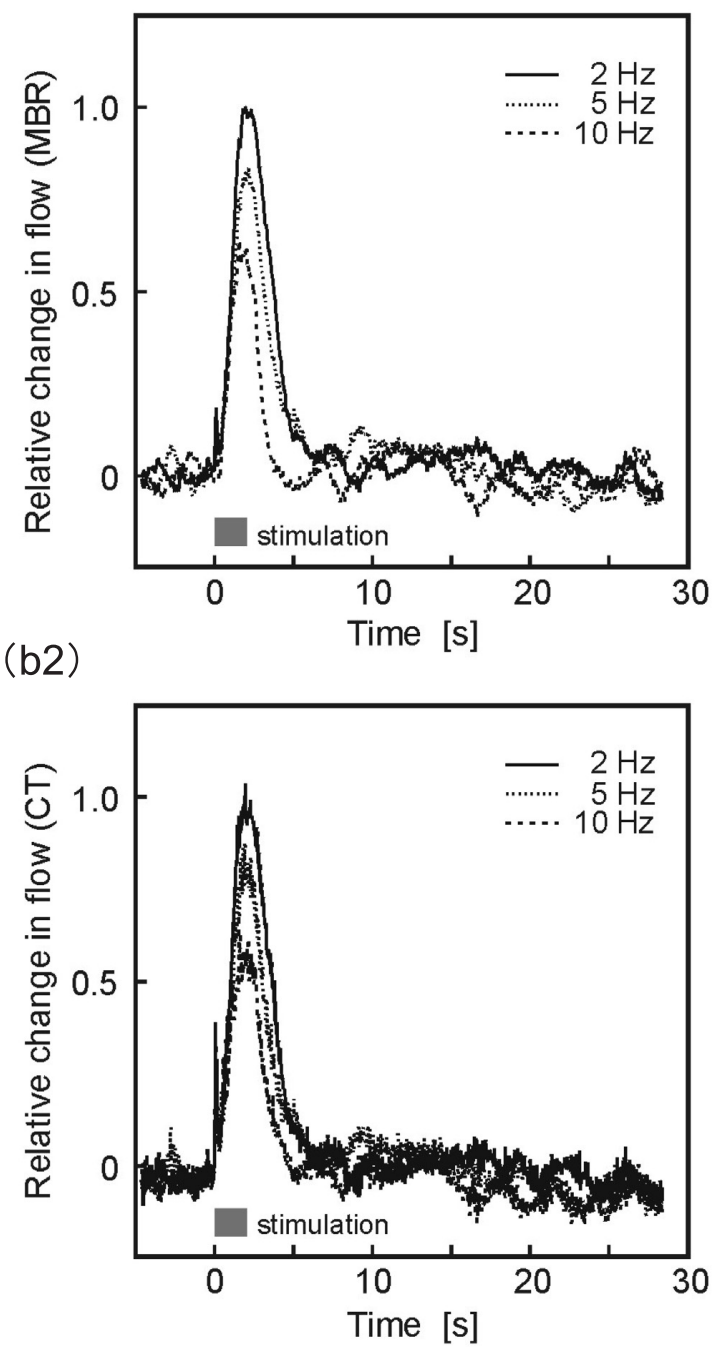

Fig. 3 Temporal change in blood flow in the cortical tissue of a mouse evoked by whisker stimulation measured by (a) LDF and LSFG ((b1) MBR and (b2) SC). The duration of the stimulation is $2 \mathrm{~s}$.
それぞれ示している。レーザースペックル法，レーザー ドップラー法のいずれも絶対量として血流速を求めるこ とはできないため，それぞれの流速評価值は，ベースラ イン計測時の值と $10 \mathrm{~Hz}$ の空気圧刺激を行ったときの最 大值で正規化してある、いずれの流速評価值も，刺激開 始 (時刻0) 直後に血流が増加し, 刺激終了後にベースラ インに戻っている。また，ヒゲに与える空気圧の周波数 を高くすることで, 脳血流変化のピーク值が大きくなる ことに関しても同一の傾向が見られる。スペックル法に よって求めた2つの流速評価值を比較すると，3フレーム の $2 \times 2$ 画素から求めたMBR 值は, 1 フレームの7 7 7画素 から求めたCT值に比へて計算に用いる総画素数は少な いが，ノイズの少ない血流速波形が得られていることが 分かる. Fig. 3 (a)に示したレーザードップラー法によ る脳血流変化に対して、レーザースペックル法によって 計測したMBR值 (Fig. 3 (b1)) とCT值 (Fig. 3 (b2))の変化 の相関を求めた結果をFig. 4 (a)，（b）にそれぞれ示す. 空気圧刺激の周波数が $2 ， 5,10 \mathrm{~Hz}$ のときの血流速波形 の相関係数は，MBR值が $0.89 ， 0.92 ， 0.96, \mathrm{CT}$ 值が 0.85 , 0.93，0.96となった。レーザースペックル法で求めた脳

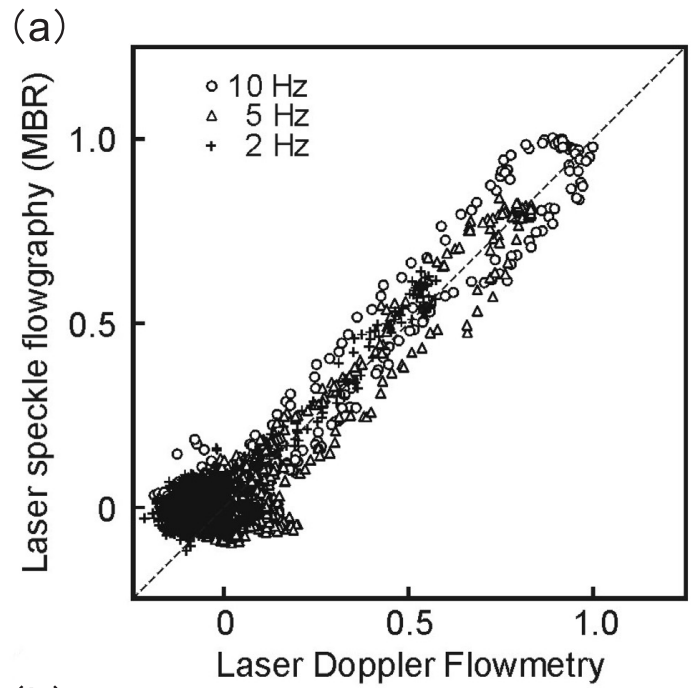

(b)

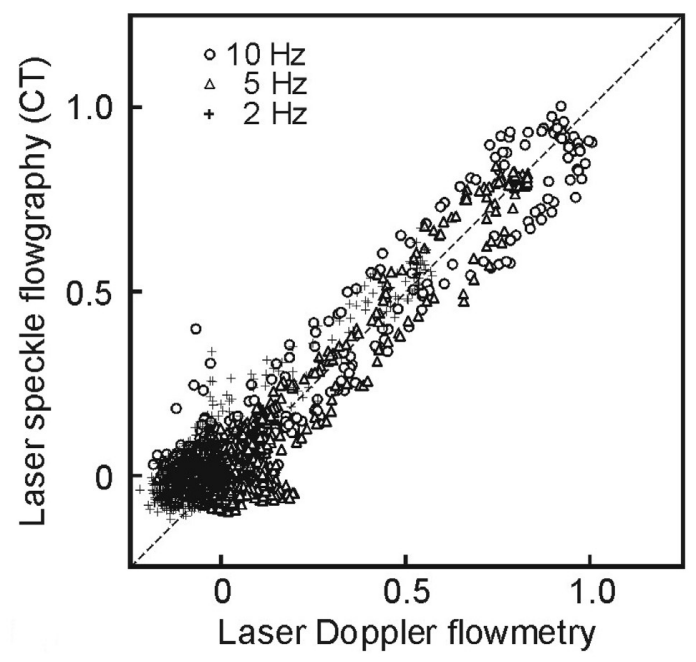

Fig. 4 Correlation of change in blood flow measured by LDF and LSFG ((a) MBR and (b) SC). The duration of the stimulation is $2 \mathrm{~s}$. 
血流変化は, MBR值，CT值のいずれを用いた場合でも レーザードップラー法で計測した結果と高い相関が認め られる。

空気圧の周波数 $10 \mathrm{~Hz}$ でヒゲ刺激を 20 秒間行ったとき の血流変化をレーザースペックル法とレーザードップ ラー法で計測した結果をFig. 5に示す。刺激開始直後は, 2秒間の刺激を行った場合とほぼ同様に脳血流が増加し ている。刺激が継続した場合, 刺激開始後約3秒過ぎか ら脳血流が一旦減小し, 刺激後約8秒過ぎから再び増大 する傾向が見られた。 この傾向は, レーザードップラー 法, レーザースペックル法のいずれの計測結果でも観測 された。また， $2 \mathrm{~Hz} ， 5 \mathrm{~Hz}$ 空気圧刺激をした場合も， 時間変化の傾向は同一で, 血流変化の大きさが刺激周波 数とともに増大した．ヒゲ刺激を20秒間行ったときの血 流変化をレーザードップラー法で計測した結果とレー ザースペックル法で計測したMBR值の変化の相関を求 めた結果をFig. 6に示す。空気圧刺激の周波数が2，5, $10 \mathrm{~Hz}$ のとの相関係数は $0.95,0.96,0.98$ で, レーザー

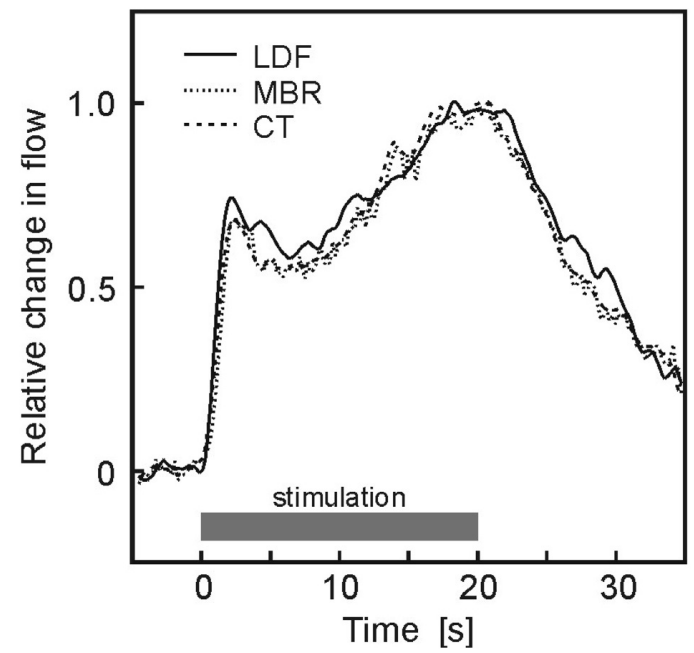

Fig. 5 Temporal change in blood flow in the cortical tissue of a mouse evoked by whisker stimulation measured by LDF and LSFG. The duration of the stimulation is $20 \mathrm{~s}$.

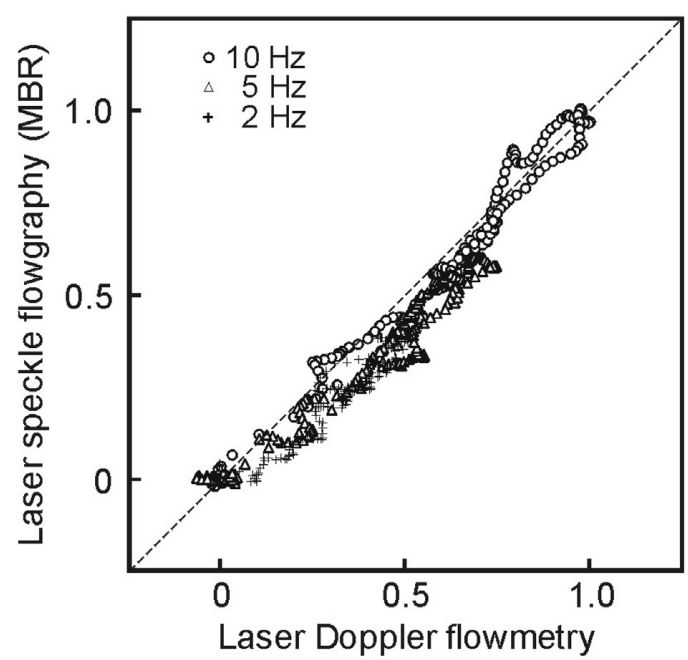

Fig. 6 Correlation of change in blood flow measured by LDF and LSFG (MBR). The duration of the stimulation is $20 \mathrm{~s}$.
スペックル法で求めたMBR值の変化は, レーザードッ プラー法で測定した脳血流変化と高い相関が認められ た.レーザースペックル法で求めたCT值についても, 同様の結果が得られた。

空気圧刺激を $10 \mathrm{~Hz}$ で2秒間行ったときに得られたス ペックルパターンから，計算に用いるフレーム数を3〜 24に変化させて求めたMBR值の時間変化波形をFig. 7に 示す。スペックル画像3フレームから求めたMBR值の時 間変化にはわずかにノイズが見られるが，8フレームか ら求めた波形ではノイズは減少している。また，24フ レームからMBR值を求めた場合でも，刺激直後に波形 の傾きが急峻に変化する部分を除いては平滑化の影響は ほとんど見られない。 ヒト網膜の血流計測では，8フ レーム程度のスペックル画像を用いれば, MBR值に よってノイズの影響が少なく血流の経時変化を追跡可能 であったと報告されており ${ }^{8)}$ 、マウスの脳血流計測にお いても，ほぼ同様の結果が得られている.

5. まとめ

レーザースペックル法による脳血流計測の流速評価值 としてMean Blur Rate (MBR) 值を用いることの妥当性を 検証するため, 同一個体のマウスの体性感覚野における 神経活動による脳血流変化を，レーザースペックル法と レーザードップラー法によって計測した。レーザース ペックル法で測定した脳血流変化は，MBR值，CT值の いずれを用いた場合でも，レーザードップラー法による 血流結果と高い相関が得られた。1フレームのスペック ルパターンの空間分布から算出されるCT值と比較して, 複数フレームのスペックルパターンの時空間分布から算 出したMBR值は，よりノイズの影響が少ない結果が得 られ，複数フレームを用いることが時間分解能に及ぼす 影響もみられなかった。 これらの結果から，MBR值を 用いたスペックル法を小動物の脳血流計測に適用するこ とは妥当かつ有効であると考えられる。

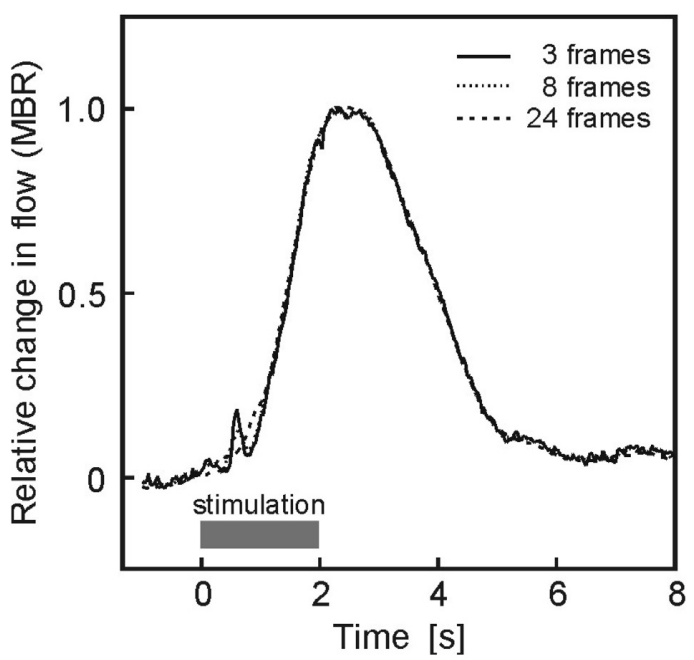

Fig. 7 Influence of number of frames for calculation of cerebral blood flow on the result of the temporal change in the cerebral blood flow. 


\section{謝 辞}

本研究を実施するにあたり，マウスの脳血流計測に対 してご協力いただいた放射線医学総合研究所分子イメー ジング研究センター田桑弘之研究員, 小畠 隆行客員研 究員, レーザースペックルフローグラフィーのシステム 構築にあたって多くのご指導を頂いた九州工業大学 藤居仁名誉教授に謝意を表します。

\section{参考文献}

1) H. Kameyama, K Masamoto, Y. Imaizumi, T. Omura, T. Katura, A. Maki, and K. Tanishita: Brain Research 1244 (2008) 82.

2) I. Ferezou, S. Bolea, and C. C. H. Petersen: Neuron 50 (2006)
617

3) J. A. Detre, B. M. Ances, K. Takahashi, and J. H. Greenberg: Brain Research 796 (1998) 91.

4) B. M. Ances, J. H. Greenberg, and J. A. Detre: NeruroImage 10 (1999) 716.

5) A. K. Dunn, H. Bolay, M. A. Moskowitz, and D. A. Boas: J. Cerebral Blood Flow and Metabolism 21 (2001) 195.

6) J. D. Briers and S. Webster: J. Biomed. Opt. 1 (1996) 174.

7) G. Royl, C. Leithner, H. Sellien, J. P. Müller, D. Megow, N. Offenhauser, J. Steinbrink, M. Kohl-Bareis, U. Dirnagl, and U. Lindauer: Brain Research 1121 (2006) 95.

8）小西直樹, 戸笠 由紀子, 恒松 裕朋, 藤居仁：光学 $\mathbf{3 1}$ (2001) 39.

9) N. Konishi, Y. Tokimoto, K Kohra, and H. Fuji: Optical Review 9 (2002) 163.

10) H. Takuwa, J. Autio, H. Nakayama, T. Matsuura, T. Obata, E. Okada, K. Masamoto, and I. Kanno: Brain Research 1369 (2011) 103. 